\title{
Meta-Analysis the Effect of Intrauterine Device Uptake on the Risk of Ectopic Pregnancy in Women of Reproductive Age
}

\author{
Yulita Endah Mayaningrum(1), Eti Poncorini Pamungkasari²), Bhisma Murti1) \\ ${ }^{1)}$ Masters Program in Public Health, Universitas Sebelas Maret \\ ${ }^{2)}$ Faculty of Medicine, Universitas Sebelas Maret
}

\section{ABSTRACT}

Background: Indonesia has a high Maternal Mortality Rate (MMR) and has not met the Millennium Development Goals (MDGs) target. Maternal mortality in Indonesia is caused by bleeding, hypertension, infection with abortion, and prolonged labor. One of the causes of bleeding in the first trimester is ectopic pregnancy. Several studies have shown an increased risk of ectopic pregnancy in women using intrauterine contraceptives.

Subjects and Method: A literature review was carried out in this study with a case control study design. The exposure was intrauterine contraception, and the outcome of the study was an ectopic pregnancy. The initial screening limits studies by time, language and appropriate themes. Furthermore, the selection of research articles was carried out based on the content according to the topic, namely ectopic pregnancy and intrauterine contraceptives, the literature obtained was not duplicated, and each literature was reviewed. Statistical analy- sis was performed using Rev.Man 5.3 software with a random effects model. Value: the I2 statistic was used to calculate heterogeneity.

Results: Pooled OR estimates from all studies are $(\mathrm{RR}=1.53 ; 95 \% \mathrm{CI}=0.48$ to $4.80 ; \mathrm{p}=0.47)$ with a heterogeneity of $85 \%$.

Conclusion: Based on a review of the literature, it can be concluded that intrauterine contraceptives can cause ectopic pregnancy, but the results of the study still show quite varied OR.

Keywords: intrauterine contraceptives, ectopic pregnancy, meta analysis

\section{Correspondence:}

Yulita Endah Mayaningrum. Masters Program in Public Health, Universitas Sebelas Maret. Jl. Ir. Sutami 36 A, 57126, Surakarta, Central Java 57126. Email: yulita.maya95@gmail.com. Mobile: +6285817887585 .

Cite this as:

Mayaningrum YE, Pamungkasari EP, Murti B (Year). Meta-Analysis the Effect of Intrauterine Device Uptake on the Risk of Ectopic Pregnancy in Women of Reproductive Age. J Matern Child Health. 06(02): 165-175. https://doi.org/10.26911/thejmch.2021.06.02.04.

cc) (i) (2) Journal of Maternal and Child Health is licensed under a Creative Commons Attribution-NonCommercial-ShareAlike 4.o International License.

\section{BACKGROUND}

The Indonesian government is committed to improving the health status of its population by setting health development goals. One of the goals of health development in Indonesia is to increase the degree of maternal health using the Maternal Mortality Rate (MMR) indicator (Kemenkes RI, 2015).

MMR in Indonesia is still quite high. This is in view of the achievement of decreasing MMR in several ASEAN countries. MMR in ASEAN countries has reached the position of $40-60$ per 100 thousand live births. Based on the InterCensus Population Survey (SUPAS) it still occupies the position of 305 per 100 thousand live births. Meanwhile, data on the performance achievements of the Indonesian Ministry of Health in 2015-2017 shows that there has been a decrease in the number of cases of maternal mortality. If in 2015 MMR reached 4,999 cases, then in 
2016 it decreased slightly to 4,912 cases and in 2017 it decreased sharply to 1,712 MMR cases (BPS, 2015).

The causes of maternal death in Indonesia consist of bleeding, hypertension, infection, abortion, total and prolonged labor. The direct factors that cause maternal death include late decision making, late arrival at the hospital, late treatment at the hospital, and complications. Indirect factors that cause maternal mortality include completeness of antenatal care visits, the presence of pregnancy risk factors, maternal education, and maternal occupation (Fransiska, 2017). In addition, the cause of maternal death is the number of antenatal care visits which are less than 4 times during pregnancy and also the presence of complications during pregnancy (Masturoh, 2017).

There are several causes of bleeding after childbirth, including anemia and also a history of bleeding after childbirth during previous labor (Saadah, 2016). Bleeding after childbirth is also directly affected by delivery distance, antenatal care visits and type of delivery (Puspitasari, 2017).

One other cause of bleeding is an ectopic pregnancy which occurs early in pregnancy. Ectopic pregnancy is a pregnancy outside the uterus, usually occurs in the fallopian tubes, if there is interference with an ectopic pregnancy, there will be heavy bleeding in pregnant women which requires emergency action (Lawani et al., 2013).

The incidence of ectopic pregnancy tends to increase. Based on several studies, the risk factors for ectopic pregnancy consist of history of Pelvic Inflamatory Diseases (PID), history of previous ectopic pregnancy, history of surgery on the fallopian tubes, history of surgery on the abdomen accompanied by adhesions, endometriosis, use of exogenous hormones such as the hormone progesterone or estrogen, congenital abnormalities in the form of fallopian tube abnormalities, use of IUD contraceptives, history of infection, and smoking (Bouyer, 2003).

Ectopic pregnancy is an emergency situation that causes maternal death during the first trimester of pregnancy. Most of the extrauterine implantations occur in the fallopian tubes. The most frequent sites were the ampulla (80\%), then the ismic pars (12\%), the fimbria (5\%), and the intersisial pars (0.2\%), respectively, the implantations that occurred in the ovary (0.2\%) and the cervix. (0.2\%). The ectopic pregnancy incidence rate in the United States has more than tripled during the 16.8 / 1000 years of pregnancy. Data Centers for Disease Control Prevention, Incidence Rate. Ectopic pregnancies in the United States in 1997-2000 experienced an increase of $20.7 / 1000$ pregnancies (Speroff, 2005).

The intrauterine device (IUD) is one of the most widely used contraceptive methods in the world. Globally, $14.3 \%$ of women of reproductive age choose to use intrauterine devices as their method of contraception. There are more users of intrauterine devices in developing countries (24.7\%) than in developed countries (12.7\%). The consecutive rates of intrauterine contraceptive use were Asia (27\%), followed by Europe (17.1\%), Africa (15.4\%), Latin America (9.6\%), North America (6.1\%), and Oceania (1.8\%). Data collected by the National Family Planning Committee has shown that women of reproductive age have increased the use of intrauterine devices from $42.1 \%$ in 1988 to $48 \%$ in 2006 (Buhling KJ et al., 2014). Many women choose to use intrauterine devices because they have to work outside the home and because they don't want to experience the side effects of using other contra- 
ceptives such as pills or injections (Ningrum, 2016).

Further analysis of the effect of intrauterine contraceptive use on ectopic pregnancy is needed to reach conclusive conclusions. Therefore, we are interested in conducting a systematic review and metaanalysis of the results of studies relating to the effect of intrauterine contraceptive use on the risk of ectopic pregnancy in women of reproductive age.

\section{SUBJECTS AND METHOD \\ 1. Study Design}

This study is a systematic review and metaanalysis. Systematic reviews and metaanalyzes are carried out by collecting all related studies (topics and designs) then reviewing and re-analyzing the research results (Kang, 2015). A meta-analysis study is valid, objective and is a scientific method that analyzes and brings together different results (Uetani et al., 2009).

\section{Inclusion Criteria}

Inclusion criteria for articles that can be studied are articles must be full paper, appropriate title, mentioning women of reproductive age, IUD, and ectopic pregnancy, articles using observational study design (cross-sectional), articles using English, multivariate analysis used with the adjusted Odds Ratio, the intervention given was IUD users, the study subjects were women of reproductive age and the outcome was ectopic pregnancy.

\section{Exclusion Criteria}

The exclusion criteria for articles included studies conducted with RCTs, case controls, quasi experiments, protocol studies and pilot studies and not multivariate analysis studies.

\section{Operational Definition Variables}

An ectopic pregnancy is a pregnancy in which a fertilized egg implants and grows outside the endometrium of the uterine cavity.

The intrauterine device (IUD) is a contraceptive device that is placed in the uterus by clamping the two tubes that produce the ovaries so that fertilization does not occur, consisting of polyethylene plastic, some are wrapped around copper and some are not.

\section{Instruments}

The instrument for this study was a published article that identified the effect of intrauterine device use and age on the risk of ectopic pregnancy in women of reproductive age.

Data processing consists of the process of identifying articles from several reputable journal sites, followed by a screening process for articles that meet the requirements and conditions of the researcher so that several articles that pass the eligibility stage are obtained and finally an analysis is carried out by determining the results of the research to be further processed in special meta-analysis software.

\section{Data Analysis}

The research that has been collected is selected by predetermined criteria. This research is a meta-analysis study. This study uses secondary data in the form of data from previous research results and data processing is carried out using the Review Manager (RevMan 5.3) (Widyaningsih, 2019). The meta-analysis study also looked at the value of the effect size and heterogeneity to determine the model for combining research and forming the final meta-analysis result in the form of a forest plot. The effect size calculation is done by using the adjusted Odds Ratio (aOR) value for each study. Then the effect size is sought for diversity by heterogeneity test to determine the amalgamation model. The fixed effect model assumes that the 
variability among studies is based solely on the opportunity factor. The random effect model was used to assess intra-study variability as well as taking into account the inter-study variability. After the model is determined, each study is calculated to determine the summary effect or the final result of the meta-analysis (Prasiska, 2014).

\section{RESULTS}

The search process was carried out on articles published between 2000 and 2020. The databases used were PubMed, Science Direct, Research Gate, and Google Scholar.

The final results of the review articles obtained 7 articles that met the quantitative requirements for meta-analysis. Two articles are from the continent of Asia, 3 articles from the continent of Europe and 2 articles from the continent of America. Furthermore, the researchers conducted an assessment of the quality of the articles (Table 1).

The use of intrauterine devices against the risk of ectopic pregnancy in women of reproductive age

Table 2 provides information on 7 articles with a case-control study design as a metaanalysis source of intrauterine contraceptive use against the risk of ectopic pregnancy in women of reproductive age.

\section{a. Forrest plot}

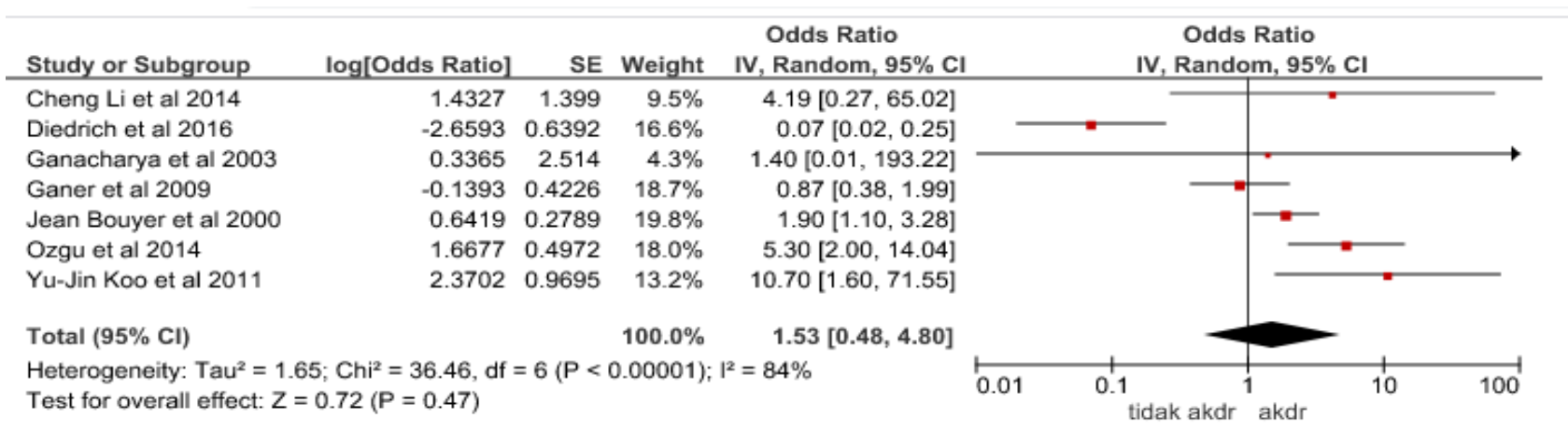

Figure 1. Forest Plot of the effect of intrauterine devices on the risk of ectopic pregnancy in women of reproductive age

\section{b. Funnel Plot}

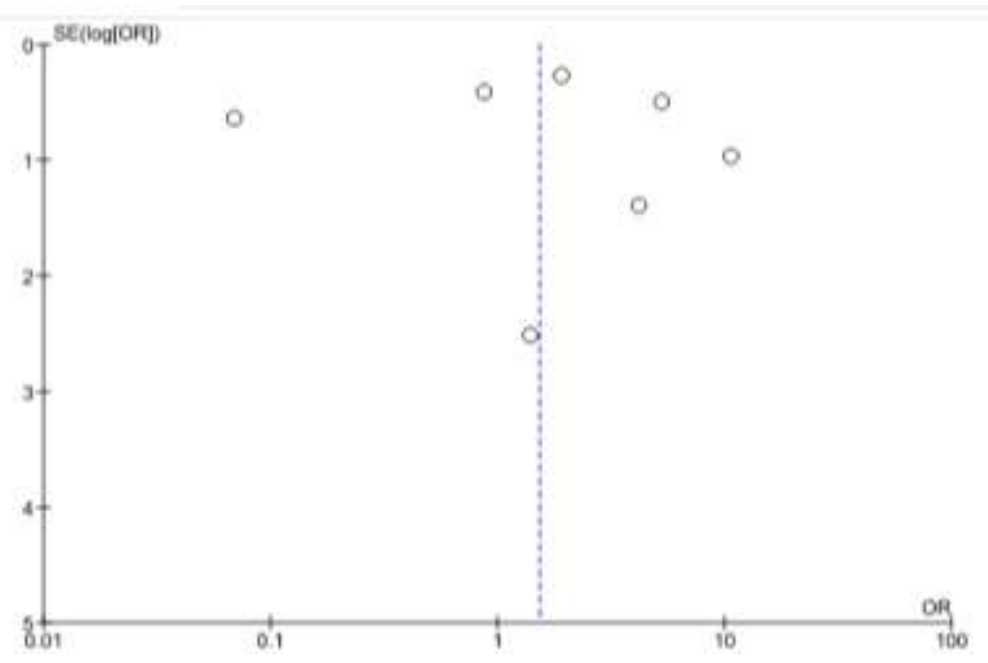

Figure 2. Funnel Plot of the effect of intrauterine contraceptives on the risk of ectopic pregnancy in women of reproductive age 
Mayaningrum et al./ Effect of Intrauterine Device Uptake on the Risk of Ectopic Pregnancy

Figure 1. Forest plot shows that the use of intrauterine devices increases the risk of ectopic pregnancy in women of reproductive age by 1.53 times. The distribution of data is stated to be heterogeneous (random effect model) which is shown from the $\mathrm{I}^{2}$ value of $85 \%$.

Figure 2 funnel plot the effect of intrauterine contraceptive use, the plots on the right and left sides are not symmetrical with each other and do not form an inverted funnel. The plot has a standard error of $>$ 0.6. In addition, there is 1 plot on the left side that is away from the vertical center line. This indicates that there is a publication bias in the study. 
Table 1. Assessment of Research Quality

\begin{tabular}{|c|c|c|c|c|c|c|c|c|c|c|}
\hline Publication & Cohort & $\begin{array}{l}\text { With the } \\
\text { control } \\
\text { group }\end{array}$ & $\begin{array}{l}\text { Pre/ post } \\
\text { inter- } \\
\text { vention }\end{array}$ & $\begin{array}{c}\text { Random } \\
\text { assignment }\end{array}$ & $\begin{array}{c}\text { Random } \\
\text { selection } \\
\text { for } \\
\text { assessment }\end{array}$ & $\begin{array}{c}\text { Sample } \\
\text { Size } \\
(>100)\end{array}$ & $\begin{array}{c}\text { Follow } \\
\text { up rate } \\
\geq 80 \%\end{array}$ & $\begin{array}{c}\text { Comparable } \\
\text { sociodemo- } \\
\text { graphic } \\
\text { between study } \\
\text { arms } \\
\end{array}$ & $\begin{array}{c}\text { Comparable } \\
\text { baseline out- } \\
\text { come measures } \\
\text { between } \\
\text { Study arms } \\
\end{array}$ & Total \\
\hline $\begin{array}{l}\text { (Cheng Li et } \\
\text { al., 2014) }\end{array}$ & 1 & 1 & 1 & 1 & 1 & 1 & 1 & 1 & 1 & 9 \\
\hline $\begin{array}{l}\text { (Yu-Jin et al., } \\
\text { 2011) } \\
\text { (Jean Bouyer }\end{array}$ & 1 & 1 & 1 & 1 & 1 & 1 & $\mathrm{O}$ & 1 & 1 & 8 \\
\hline et al., 2000) & 1 & 1 & 1 & 1 & 1 & 1 & o & 1 & 1 & 9 \\
\hline $\begin{array}{l}\text { (Ganacharya } \\
\text { et al., 2003) }\end{array}$ & 1 & 1 & 1 & 1 & 1 & 1 & 1 & $\mathrm{O}$ & 1 & 8 \\
\hline $\begin{array}{l}\text { (Ozgu et al., } \\
\text { 2014) }\end{array}$ & 1 & 1 & 1 & 1 & 1 & 1 & $\mathrm{O}$ & 1 & 1 & 9 \\
\hline $\begin{array}{l}\text { (Diedrich et } \\
\text { al., 2016) }\end{array}$ & 1 & 1 & 1 & 1 & 1 & 1 & o & 1 & 1 & 9 \\
\hline $\begin{array}{l}\text { (Ganer et } \\
\text { al., 2009) }\end{array}$ & 1 & 1 & 1 & 1 & 1 & 1 & o & 1 & 1 & 9 \\
\hline
\end{tabular}

Table 2. Summary Source of the effect of intrauterine contraceptive use on the risk of ectopic pregnancy in women of reproductive age

\begin{tabular}{|c|c|c|c|c|c|c|}
\hline Author, year & Location & $\begin{array}{l}\text { Sample } \\
\text { Size }\end{array}$ & $\begin{array}{l}\text { Intervention (I) and Comparator } \\
\text { (C) }\end{array}$ & Outcome & OR (95\% CI) & $\begin{array}{l}\text { RR (95\% } \\
\text { CI) }\end{array}$ \\
\hline $\begin{array}{l}\text { (Chengli et al., } \\
\text { 2014) }\end{array}$ & China & 1789 & $\begin{array}{l}\text { I: women with a planned pregnancy but } \\
\text { experiencing ectopic pregnancy } \\
\text { C: Intrauterine pregnancy }\end{array}$ & $\begin{array}{l}\text { Ectopic } \\
\text { pregnancy }\end{array}$ & $4.19(0.27-6.89)$ & - \\
\hline $\begin{array}{l}\text { (Yu-jin Koo et } \\
\text { al., 2011) }\end{array}$ & South Korea & 253 & $\begin{array}{l}\text { I: ovarian pregnancy } \\
\text { C: surgery outcomes }\end{array}$ & $\begin{array}{l}\text { Ectopic } \\
\text { pregnancy }\end{array}$ & $10.7(1.6-46.4)$ & - \\
\hline $\begin{array}{l}\text { (Jean Bouyer et } \\
\text { al., 2000) }\end{array}$ & France & 383 & $\begin{array}{l}\text { I: women of reproductive age using } \\
\text { intrauterine contraceptives } \\
\text { C: reproductive woman using IUD and } \\
\text { suffering from ectopic and intrauterine } \\
\text { pregnancy }\end{array}$ & $\begin{array}{l}\text { Ectopic } \\
\text { pregnancy }\end{array}$ & $1.9(1.1-3.2)$ & - \\
\hline
\end{tabular}


Mayaningrum et al./ Effect of Intrauterine Device Uptake on the Risk of Ectopic Pregnancy

\begin{tabular}{|c|c|c|c|c|c|c|}
\hline $\begin{array}{l}\text { (Ganacharya et } \\
\text { al., 2003) }\end{array}$ & Hungary & 3491 & $\begin{array}{l}\text { I: women who don't use IUDs } \\
\text { C: women who use IUDs }\end{array}$ & $\begin{array}{l}\text { Ectopic } \\
\text { pregnancy }\end{array}$ & $1.4(0.9-8.9)$ & - \\
\hline $\begin{array}{l}\text { (Ozgu et al., } \\
\text { 2019) }\end{array}$ & Turkey & 114 & $\begin{array}{l}\text { I: pregnancy after using the IUD } \\
\text { C: the effect of the placement of the IUD }\end{array}$ & $\begin{array}{l}\text { Ectopic } \\
\text { pregnancy }\end{array}$ & - & $5.3(2.0-10.8)$ \\
\hline $\begin{array}{l}\text { (Diedrich et al., } \\
\text { 2016) }\end{array}$ & $\begin{array}{l}\text { United } \\
\text { States of } \\
\text { America }\end{array}$ & 574 & $\begin{array}{l}\text { I: use of the IUD in women }<25 \text { years } \\
\text { C: use of implants }\end{array}$ & $\begin{array}{l}\text { Ectopic } \\
\text { pregnancy }\end{array}$ & $0.07(0.02-0.34)$ & $\begin{array}{l}0.10\left(0.03^{-}\right. \\
\quad 0.34)\end{array}$ \\
\hline $\begin{array}{l}\text { (Ganer et al., } \\
\text { 2009) }\end{array}$ & $\begin{array}{l}\text { United } \\
\text { States of } \\
\text { America }\end{array}$ & 292 & $\begin{array}{l}\text { I: pregnancy by maintaining } \\
\text { contraceptives in the uterus } \\
\text { C: pregnancy without intrauterine } \\
\text { contraceptives }\end{array}$ & $\begin{array}{l}\text { Ectopic } \\
\text { pregnancy }\end{array}$ & $0.87(0.38-2.09)$ & $\begin{array}{l}0.93\left(0.55^{-}\right. \\
\quad 1.57)\end{array}$ \\
\hline
\end{tabular}




\section{DISCUSSION}

Ectopic pregnancy is a pregnancy with a fertilized ovum that implants and grows not in a normal place, namely in the endometrium of the uterine cavity (Wiknjosastro, 2007).

Signs and symptoms according to Wiknjosastro in 2007 include amenorrhoea, which is often found, although only briefly before bleeding, nausea and vomiting, pain in the right or left side of the mother's stomach, the stomach gets bigger and harder, body temperature slightly rises, pulse is fast and pressure decreased blood.

Types of ectopic pregnancy (Wiknjosastro, 2007) include cervical pregnancy, uterine diverticulum pregnancy, ovarial pregnancy, intra and extra uterine pregnancy, abdominal pregnancy.

The factors that cause ectopic pregnancy include tubal factors, abnormalities of the zygote, ovarian factors, hormonal factors on the acceptors of birth control pills and other factors included here, among others, the use of IUDs (Saifuddin, 2009).

This research is a systematic study and meta-analysis. The aim of this study was to draw conclusions from the results of similar studies examining the effect of intrauterine contraceptive use on the risk of ectopic pregnancy in women of reproductive age. The primary studies involved in this research are those conducted in various countries and races, in order to obtain conclusions that can be generally applied as a basis for intervention.

The results of the meta-analysis are presented in the form of a forest plot diagram and a funnel plot. The forest plot is a graphical representation of the metaanalysis results that includes information related to the incorporation of the results from the primary study. Then, on the right side there is a line representing each study conducted by the meta-analysis which is plotted according to its weighting. Visually, the forest plot can also show the amount of heterogeneity between study results (Akobeng, 2005 in Murti, 2018).

A funnel plot is a diagram in a metaanalysis that illustrates the possibility of publication bias. In this case, the funnel plot shows the relationship between the effect size of the study and the sample size or standard error of the effect size of each study studied. The bias shown by the funnel plot can be seen by assessing the asymmetry of the study (the number of points on the right and left sides) compared to the standard error and the imbalance of the number of studies on the right and left (Murti, 2018).

The results of a meta-analysis of 7 articles on the effect of intrauterine contraceptive use on the risk of ectopic pregnancy in women of reproductive age are summarized in a forest plot. Forest plot in Figure 2. demonstrated that the effect of intrauterine contraceptive use can increase 1.53 times the risk of developing an ectopic pregnancy in women of reproductive age. There was high heterogeneity between experiments $\left(I^{2}=84 \% ; p<0.0001\right)$ so a random-effect (REM) model was used. These results were statistically significant RR 1.53; 95\% CI = 0.48-4.80; $\mathrm{p}=0.47$.

These results are supported by Bouyer et al. (2000), that there are several factors that increase the risk of ectopic pregnancy, including the use of intrauterine contraceptives. Progesterone in intrauterine devices is associated with a higher risk of ectopic pregnancy. In this study it was also stated that the duration of women who used intrauterine contraceptives for more than 2 years had a twofold risk of experiencing an ectopic pregnancy compared to women who used intrauterine contraceptives for less or equal to 2 years, even if the risk of ectopic 
pregnancy was higher previously used intrauterine contraceptives for more than 6 years.

In another research that supports Skjeldest (1997). In their, it was stated that the increase in the use of intrauterine devices by women of reproductive age in gia in the 1980 s to the 1990 s contributed to an increase in the incidence of ectopic pregnancies in these countries.

This study is also supported by Cheng Li et al., (2014). In their study, it was stated that women of reproductive age who used intrauterine contraceptives previously for a long time would increase their risk of developing an ectopic pregnancy, even though the intrauterine contraceptive device had been taken.

Piggot et al. (2019) concluded that the use of intrauterine devices is associated with an increased risk of ectopic pregnancy. This is because intrauterine devices are specially designed to prevent fertilization from occurring in the uterus.

\section{AUTHOR CONTRIBUTION}

Yulita Endah Mayaningrum is the main researcher who acts as the main researcher who plays a role in coordinating the research, conducting all stages of the research, and completing the research paper. Bhisma Murti played a role in compiling the research head, processing research data, presenting the results of research analysis, and preparing research papers. Eti Poncorini Pamungkasari plays a role in developing ideas, research designs, and research hypotheses.

\section{CONFLICT OF INTEREST}

There is no conflict of interest in this study.

FUNDING AND SPONSORSHIP

This study is self-funded.

\section{ACKNOWLEDGEMENT}

None.

\section{REFERENCE}

Badan Penelitian dan Pengembangan Kesehatan Kemenkes RI (2013).Riset Kesehatan Dasar (RISKESDAS). Laporan Nasional.

Bouyer J (2003). Epidemiology of ectopic pregnancy: Incidence, risk factors and outcomes. J Gynecol Obs Biol Reprod. 32(7): 8-17. https://pubmed.ncbi.nlm.nih.gov.

Bouyer J, Rachou E, Germain E, Fernandez $\mathrm{H}$, Coste J, Pouly JL, Job-Spira N (2000). Risk factors for extrauterine pregnancy in women using an intrauterine device. Fertil. Steril. 74(5): 899-908. https://doi.org/10.1016/So015-0282(00)01605-8.

Buhling KJ, Zite NB, Lotke P, Black K (2014). Worldwide use of intrauterine contraception: a review. Contraception. 89(3): 162-173. https://doi.org/10.1016/j.contraception.2013.11.011

Center for Evidence Based Management (2014). Critical Appraisal Checklist for Cross-Sectional Study.

Li C, Meng CX, Zhao WH, Lu HQ, Shi W, Zhang J (2014). Risk factors for ectopic pregnancy in women with planned pregnancy: A case-control study. Eur J Obstet Gynecol Reprod Biol 182(1): 176-182. https://doi.org/10.1016/j.ejogrb.2014.07.049

Fransiska RD, Respati SH, Mudigdo A (2017). Analysis of maternal mortality determinats in Bondowoso District, East Java. J Matern Child Health 2(1): 76-88. https://doi.org/10.26911/thejmch.2017.02.01.08.

Hoetomo (2005). Kamus Lengkap Bahasa Indonesia. Jakarta: Mitra Pelajar Swadaya

Kang H (2015). Statistical considerations in meta-analysis. Hanyang Med Rev. 
Mayaningrum et al./ Effect of Intrauterine Device Uptake on the Risk of Ectopic Pregnancy

35(1): 23-32. https://doi.org/10.7599/hmr.2015.35.1.23.

Kemenkes RI (2014). Pedoman Pelayanan Keluarga Berencana Pasca Persalinan di Fasilitas Kesehatan (Guidelines for Postpartum Family Planning Services in Health Facilities). Jakarta: Kemenkes RI.

Kemenkes RI (2015). Rencana Strategis Kementerian Kesehatan Tahun 20152019 (Ministry of Health Strategic Plan 2015-2019). Jakarta: Kementerian Kesehatan

Lawani OL, Anozie OB, Ezeonu PO (2013). Ectopic pregnancy: A life-threatening gynecological emergency. Int $J$ Womens Health. 5(1): 515-21. https://doi.org/10.2147/IJWH.S49672.

Masturoh, Respatih SH, Murti B (2017). Path analysis risk factors that influence maternal mortality. J Matern Child Health 2(1): 10-19 https://doi.org/10.26911/thejmch.2017.02.01.02.

Murti B (2018). Prinsip dan Metode Riset Epidemiologi (Edisi V). Program Pascasarjana, Universitas Sebelas Maret. Surakarta: Bintang Fajar Offset.

Murti B (2010). Desain dan Ukuran Sampel untuk Penelitian Kuantitatif dan Kualitatif di Bidang Kesehatan edisi ke-2 (Design and Sample Size for Quantitative and Qualitative Research in Health, 2nd edition). Yogyakarta: UGM press.

Ningrum SS, Indarto D, Wijaya M (2016). Employment status, family income, contraceptive avaibility, and their effects on the use of long term contraceptives in Sukoharjo, Central Java. J Matern Child Health 1(3): 179-187 https://doi.org/10.26911/thejmch.2016.01.03.05.

Prasiska D (2014). Analisis faktor risiko berat badan lahir pada kematian perinatal menggunakan meta analysis
(Analysis of risk factors for birth weight in perinatal mortality using a meta analysis). Jurnal Biometrika Kependudukan. 3(1): 28-33.

Neth MR, Thompson MA, Gibson CB, Gullett JP, Pigott DC (2019). Ruptured ectopic pregnancy in the presence of an intrauterine device. Clin Pract Cases Emerg Med. 3(1): 51-54. https://doi.org/10.5811/cpcem.2019.1.41345.

Ratna P, Hastuti URB, Murti B (2017). Risk factors of postpartum hemorhage in Bondowoso District, East Java. J Matern Child Health. 2(2): 177-187 https://doi.org/10.26911/thejmch.2017.02.02.08.

Saadah M, Respati SH, Aristin OP (2016). Multilevel analysis on the risk factors of post partum hemorrhage in Bondowoso, Central Java. J Matern Child Health. 1(4): 205-213 https://doi.org/10.26911/thejmch.2016.01.04.01.

Rusmini (2017). Pelayanan KB dan Kesehatan Reproduksi Berbasis Evidence Based (Evidence Based Based Family Planning and Reproductive Health Services). Jakarta: Trans Info Media.

Saifuddin (2009). Pelayanan Kesehatan Maternal \& Neonatal (Maternal \& Neonatal Health Services). Yayasan Bina Pustaka Sarwono Prawirohardjo. Jakarta.

Setyaningrum E (2016). Pelayanan keluarga berencana (Family planning services). Jakarta: Trans Info Media.

Skjeldestad FE (1997). How effectively do copper intrauterine devices prevent ectopic pregnancy?. Acta Obstetricia et Gynecologica Scandinavica. 76(7): 684-690. https://doi.org/10.3109/o0016349709024611.

Soetjipto HP (1955). Aplikasi meta-analisis dalam pengujian validitas aitem (The application of meta-analysis in testing 
the validity of items) (Vol. 2). Buletin Psikologi.

Survei Penduduk Antar Sensus (SUPAS). (2015) Badan Pusat Statistik (BPS) Republik Indonesia.

Sperrof L, Glass RH, Kase NG (2005). Clinical Gynecologic Endocrinology and infertility Ed 6 th. Philadelphia: Lippincott, Williams and Wilkins: 114965. http://dx.doi.org/10.20473/jn.v6i2.3986.

Uetani K, Nakayama T, Ikai H, Yonemoto N, Moher D (2009). Quality of reports on randomized controlled trials con- ducted in Japan: Evaluation of adherence to the CONSORT statement. Internal Medicine, 48(5): 307-313. https://doi.org/10.2169/internalmedicine.48.1358.

Widhiastuti H (2002). Studi meta-analisis tentang hubungan (Meta-analysis studies of relationships). Jurnal Psikologi 1(1): 28-42.

Wiknjosastro H (2007). Ilmu Kebidanan (Midwifery Science). Edisi ke-4 Cetakan ke-2. Jakarta: Yayaan Bina Pustaka Sarwono Prawirohardjo. 